\title{
Industrial possibilities of the Forth Estuary
}

\author{
H.M. Cadell B.Sc. V.D. D.L.
}

To cite this article: H.M. Cadell B.Sc. V.D. D.L. (1918) Industrial possibilities of the Forth Estuary, Scottish Geographical Magazine, 34:5, 177-189, DOI: 10.1080/14702541808554316

To link to this article: http://dx.doi.org/10.1080/14702541808554316

曲 Published online: 30 Jan 2008.

Submit your article to this journal $2 \pi$

III Article views: 5

Q View related articles ๘ 
future to be heard, and their rights to be duly considered. No fair-minded man can dispute this principle, which, if carried out in its entirety, may lead to a convention in which thirteen Governments on the American side of the Pacific, and ten on the Asiatic side, would be represented as possessing territorial waters in that ocean. But the intrinsically greatest interests involved are predominantly those of the United States, Japan, France, and Great Britain. The difficulties of settlement might have been much less had there been any "No Man's Land" in the Pacific, but there is not only no such thing, but many parts are, on the contrary, claimed two or three times over. Manifestly, the question of most importance is what is to be done with the former possessions of Germany. It may be that although there are so many youthful and vigorous nations, and some powerful rejuvenated old ones, on the Pacific, their interests cannot be dealt with separately and apart from other regions of the globe. It is to be hoped, however, that a binding agreement may be made among peace-loving nations against fortified camps and military and naval competition in the Paoific; and that no aggressive Power may be there, for vast as the Pacific is, there is no room there for Teutonic Weltpolitik.

It is also greatly to be desired that the nations of Europe and America may not forget that the duty devolves on them to consider the well-being of the native races of the Pacific Islands. No truthful man can say that this duty has in the past received, as it should have done, the first consideration. It is a pity that at any convention for the settlement of the Pacific after the war, some power, or powers, that has no local interests to consider could not be appointed to represent and protect native rights. If one is to be guided by the recent past of Africa and the Pacific, one would conclude that the interests of the native and natural owners of those fair islands will be about the last. thing that will be thought of.

It is all very well, as far as it goes, to respect the natural rights of small and weak nations; but it would be still better to go a step further and apply the principle to those that are still smaller and weaker, to the native inhabitants of the Pacific Islands. To those that attach but small importance to this ideal it may be pointed out that the Pacific Islands without the Pacific Islanders would be of much less value than they are now. I know those Islanders well, and can assure you that from every point of view they should be preserved.

\section{INDUSTRIAL POSSIBILITIES OF THE FORTH ESTUARY.}

By H. M. CADELL of Grange, B.Sc., V.D., D.L.

$$
\text { (With Maps }{ }^{1} \text { and Illustrations.) }
$$

As years roll on and the storm still rages over land and sea without a rift in the thunder-clouds that brood over the economic horizon, the

I The maps illustrating this article will appear with the second part.-ED. S.G.M.

voL. XXXIV. 
prophets may well lift their voices and cry aloud at the vision that opens before them. But unhappily for us a large section of the community has not yet awakened to the seriousness of the situation, and the prophets preach to deaf ears, like men crying in the wilderness to the stones and sand. On the one hand we see an appalling mountain of national debt towering higher every day, and on the other we observe light-hearted spendthrifts gaily planning how it is to be piled still higher after the war.

Like the grandehildren of the conquering Hebrews, large numbers of the present generation have come into a goodly heritage, a land full of wells that they digged not and vineyards and olive trees that they planted not, and they are even now planning to have an easy time when the war is over, with less work and more pay and everlasting peace and comfort all round. That certainly is the wrong road to Utopia, but the right one to the state of easy-going indolence and degeneracy that will end in final destruction by more strenuous races. The plain truth is that we will have to dig and plant diligently for ourselves, think harder, work harder, and live more plainly in future if the war is to end in a blessing and not a curse to what remains of the nation's manhood.

More capital must be created, not less, and the American Labour leader, Mr. Gompers, Iately stated the truth very plainly to his party, and his words should be reiterated here, that if capital is destroyed, labour is destroyed with it. At such a time as this it is necessary to speak out, and, so far as experience goes, to direct the thoughts and energies of the community into practical and useful channels. But energy, however well intentioned and strenuous, may easily be misdirected. Wo do not need to go far afield to discover instances of loss caused by bad planning and ill-considered schemes. The Scotland Street Railway Tunnel under the New Town of Edinburgh is a small example, and the Calsdonian Canal a larger one. How many useless and costly lines have been laid, and harbours constructed both here and in our Colonies for which there was no sufficient geographical or economic reason. Political interests have created railways in Australia that are now derelict, and industrial jealousy and greed have been the cause of much absolutely unnecessary and wasteful railway expenditure at home. Large corporations have often wasted vast sums on useless works for want of adequate initial consideration. The ambitious proposal by the Glasgow Corporation in 1914 to spend a million of public money on the (bappily defeated) Loch Voil water scheme, which was admittedly not required, may be remembered in this connection.

Now that we are faced with heavy war taxation and many years of financial trouble and want, such extravagance must stop; the money to be spent must be well spent; the greatest economy, combined with the maximum of productiveness in every department, must be rigidly practised, and all kinds of waste avoided, if we are ever to win safely through this time of trial. Such geological, geographical, and physical resources as we have must be carefully scrutinised and turned to the best advantage, and our brains and man-power marshalled and directed towards the most useful and profitable channels of productive 
activity. This investigation is already being conducted in various directions and places, and the following paper is intended to be a practical contribution to the discussion of the industrial possibilities of an important and well-defined part of Scotland, where there is wide scope for useful economic expansion in the near future.

Unlike the Clyde Estuary, the Firth of Forth is as yet only industrially developed to a very partial extent, and before the advent of the Rosyth Naval Base, the Estuary was, in spite of its great natural advantages, of comparatively little economic use to the country at large. Its trade had remained for years in a more or less stagnant condition, largely, I fear it must be confessed, on account of inadequate enterprise and foresight among its leading inhabitants. The writer may perhaps be pardoned for explaining that he has had thirty-five years of varied experience as a government geologist, a mining engineer, farmer, a resident land-owner, engaged in planting trees, building houses, working minerals, making miles of roads and streets, reclaiming land from the sea, and generally developing industry and improving his estates along the shore of the Firth of Forth and elsewhere, as well as attending to different branches of public business. $\mathrm{He}$ has, in such matters, been trained to strict economy, and can therefore lay some claim to diseuss usefully the economic possibilities of the Forth Valley with which he is very well acquainted. He has often publiahed papers on the resources of the district, but recent happenings and the needs of the time make the rediscussion of the whole subject a matter of ever-recurring public interest.

New Plans for the Future. - After the war, when the much hoped for time of peace arrives, all kinds of reconstructions are being talked ofgarden cities and occupation for disabled warriors, better dwellings and conditions of employment, afforestation, small holdings, good wages, the means of finding contentment, and useful work for all.

In the pre-war days great industrial centres have grown up in which large districts have become more and more densely populated, and unhealthy congested eity life has continued to perpetuate unnatural and undesirable conditions of existence. What is required now, it seems to me, is to plan so that trade shall not all be drawn into one or two squalid and dismal centres; but rather that the people shall be able to live under more natural rural conditions and be reasonably near their work and near the fresh air and green fields also.

Geograpfical Conditions.-Now, in the Forth Estuary, which, properly speaking, begins above the Bridge and extends as far as Alloa, we find a part of Scotland where, except at Rosyth, the ground is comparatively thinly peopled, and there is ample room for an entirely new and healthy settlement and for a readjustment of the population on modern bygienic lines. In a country like this, where the larger part of the population subsists on industry other than agriculture, the inhabitants can only thrive where there are gocd natural facilities for trade and employment. Certain geographical conditions are required before any successful settlement can begin. If there is to be final success, and the foundations of a healthy and thriving community are to be laid 
securely, the following among other conditions should, if possible, be present:-

1. Proximity to the sea, with good shelter and anchorage.

2. Flat ground along the coast for works, railways, and harbours.

3. A higher hinterland in the vicinity for residential areas.

4. Mineral resources, building materials, and adjacent coalfields.

5. Good soil for agricultural development and gardens.

6. A healthy climate and adequate gravitation water supply.

Local Advantages.-The Forth Estuary, or at least most of it, between Queensferry and Stirling has all these and other natural advantages in greater or less degree. It is fundamentally an admirable subject to work upon, and is capable, with judicious expenditure and comprehensive planning, of providing excellent sites where trade and industry can be carried on with the best results and the minimum of initial outlay and running cost, and where a large population can be spread over a wide riparian area.

It is quite probable that these suggestions may not appeal to the municipalities of the large cities already in existence, each of which is seeking to extend its boundaries and attract to its precincts a still denser population. But $I$ am speaking not in the interests of any one community or place, but on the broader lines of national welfare and public economy. The health and welfare of any large community should surely be considered before the municipal ambitions of even the most benevolent of ciric dignitaries. Rural and natural conditions of life should, as far as possible, be combined with facility for good employment where it can be created, and industry may well be scattered instead of concentrated, provided of course that such decentralisation can be advantageously and economically effected. A large part of the Firth of Forth might quite well be fringed, but not necessarily continuously, with groups of maritime works of various kinds, and the people employed in several of them might comfortably reside on the highor ground overlooking their purely industrial spheres of labour along the shore, according to the way suggested in the following pages.

Importance of the Firth of Forth.-The Forth Estuary has within recent years, and quite independently of the war, acquired a new degree of national importance. The south shore between Queensferry and Blackness forms the northern boundary of the important oilshalefield of West Lothian. Good seams of oilshale crop out at different places along the beach, and are being mined to within a short distance of the sea. The Fife coalfield on the north shore is now the most important in Scotland, and is capable of much development. Coal has also been comparatively recently opened up in the valley between Alloa and Stirling, and is being extensively mined close to the river at several places beginning at Bo'ness and Torryburn. The Rosyth Dockyard has completely changed the aspect of the coast between North Queensferry and Crombie, and what was ten years ago a quiet old-world strip of shore mainly agricultural, with quaint little red-tiled villages and declining trade, has sprung suddenly into a busy hive of industry capable of inde- 
finite expansion. The naval base has quite lately stretched its activities over to Port Edgar, which was a practically derelict tidal harbour above South Queensferry, but is now an important place bustling with warlike activity. The extensive new docks at Grangemouth, opened for trade about fifteen years ago, will doubtless become an important gate for naval supplies to Rosyth from the West of Scotland, besides accommodating a large mercantile trade when the Firth is reopened for shipping after the war. There is good anchorage in the Estuary, which is well sheltered and capacious, and with all these favouring circumstances, both natural and artificial, the question of the better development of its varied resources is worthy of the fullest consideration now.

A New Plan required.-What is required is a well considered plan of campaign, and a definite and comprehensive scheme for the improvement of the navigation and the development of trade in the Estuary. In the past, under the old laissez faire system or want of system, the Forth, unlike the Clyde, has suffered greatly from want of any intelligent public attention to its requirements. The Clyde has largely been made what it is by the operations of the Clyde Trust, and the application for generations of human brain and enterprise, and the Forth, which is fundamentally a better subject to work upon, might and should in time be made of equal-if not still greater-value to the nation.

Three Geographical Divisions.-The Forth Valley between the Bridge and Stirling is geographically divisible into three distinct parts :-

1. The eastern section, extending from Queensferry to Bo'ness and Crombie, a distance of about nine miles, is two miles wide. The banks on both sides rise steeply from the beach to a height of about 100 feet, and there is little or no level ground along the foot of the slope on which extensive works or riparian towns can be built. At some places there is a narrow flat terrace between high-tide mark and the steep bank. This is known as the 25 -feet raised beach, and is well suited for houses. The 100-feet raised beach is a higher terrace well marked at some places and absent at others. It is well developed to the west and south of Blackness, and affords another excellent building site, with a gravelly solum. The north shore as far west as Crombie Point, including the villages of Charlestown and Limekilns, is now practically all included in the Harbour of Rosyth, the western boundary of which extends across the Firth from Crombie to Carriden House, which is situated nearly two miles east of Bo'ness Harbour.

From Carriden on the south shore to Port Edgar, near Queensferry, Blackness is the only village on the coast. The old castle of Blackness stands on a rocky promontory extending for a quarter of a mile out on the foreshore, but not so far as low-water line. The Castle (see sketch) is in perfect preservation, and was until recently used for an explosive magazine and barracks for a few troops, but lately has been abandoned by the army authorities.

The rest of the south shore is at present devoted to agriculture, or is under woodlands or private policies, and is not naturally adapted for industrial enterprise, but parts of it might be developed as a residential area in the way suggested afterwards. As the whole of the north shore 
opposite is practically monopolised by Government, and is being rapidly laid out for building, no suggestions fall to be made here as to its development.

2. The next section of the Forth Valley, ten miles in length, from Bo'ness to Alloa, includes the rest of the Estuary proper. On the south side the high ground recedes, and a broad tract of flat carse land, between Bo'ness, Grangemouth, and Falkirk, forms a level plain, nearly all situated a few foet above high-tide level. At the same time there is a wide stretch of foreshore to the west of Bo'ness, somewhat over 2000 acres in extent, where the tide at the broadest part recedes $1 \frac{1}{2}$ miles from the beach to low-water line. This is all covered with mud, and with gravel banks near low-water, and is eminently capable of raclamation. Above Grangemouth there is also a large mud flat of over 800 acres that might be reclaimed, and converted into good agricultural or industrial land.

The breadth of the Firth at low-tide is about $1 \frac{1}{2}$ miles at Bo'ness, and three-quarters of a mile at Grangemouth, and the deepest water is

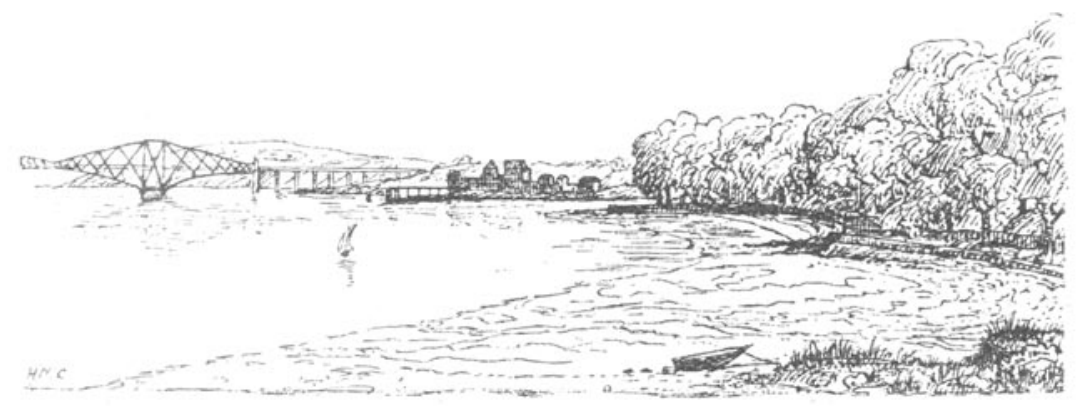

Biackness Castle and the Forth Bridge.

along the north side, where the channel is eight to nine fathoms in depth. On the north shore, opposite Bo'ness, the high ground slopes teeply up from Torry Bay, but there is here no carse land, and only a wide muddy foreshore, also capable of reclamation.

3. The remainder of the tidal section of the river from Alloa to Stirling, a distance of five miles as the crow flies, is occupied by the windings of the Forth along its fertile links. The river is crossed at Alloa by the Caledonian Railway bridge, which has proved a great impediment to shipping in the upper reaches, difficult enough already amid the meanderings of the channel on the way to Stirling.

The IIud in the Forth.-The estuary above the bridge is all more or less muddy, but the mud is most conspicuous in the upper reaches above Bo'ness, where the foreshores are almost entirely covered with a deep bed of soft impalpable silt, and the "sleeches" or "sloblands" extend up past Grangemouth to Kincardine ferry. From Bo"ness eastwards past Blackness to Queonsferry, the mud diminishes, and the foreshore becomes more sandy.

The subject of the origin and movement of the sediment in the water of the Firth has apparently never been scientifically investigated 
or discussed, and the matter deserves some notice here. It is usually assumed that all the mud, which deposits in the harbours and causes great expense in dredging, comes directly down the river in the ordinary way, and will continue to remain a natural and necessary evil for all time.

Long observation, however, leads me to conclude that this view is quite erroneous, and that it may yet be possible to diminish greatly the quantity of suspended matter, and to clarify the water so as to obviate a large part, if not all, of the dredging that is constantly needed at present. Let us first consider the physical geography of the river, and the source of its supply and drainage area.

Sources of the Forth.-The River Forth above Stirling is fed by one large tributary, the Teith, and by a smaller one, the Allan Water. The Teith is a larger stream than the Forth, and indeed the Forth is really the tributary and the Teith the main river. Now, the Teith, like all rivers that issue from lakes, is practically at all times perfectly clear and free from suspended mineral matter, as it has been filtered by passing through Lochs Lubnaig and Vennachar, and in the last thirteen miles of its course between Loch Lubnaig and its confluence with the Forth, it cannot pick up much sediment except during times of abnormal flood. After heavy rain the Forth at Stirling is no doubt brown in hue, but it is to the clear cairngorm dye of the highland peat mosses, and not to the turbidity of suspended silt, that it owes its colour.

The Allan Water is likewise clear as a rule, although it does not flow out of a large lake. The Forth above Stirling meanders sluggishly along the Vale of Menteith between alluvial clay banks, but as it has reached what geologists call its base level of erosion it cannot deepen its bed any further, and its velocity is not sufficient to transport heavy sediment. It is fed by streams flowing off the Fintry Hills and the Ben Lomond ridge, and by the Goodie Water, a clear stream issuing from. the Lake of Menteith. During times of flood the mountain burns and the Allan Water no doubt bring down some sediment, as do the Devon and the Carron Water, which enter the river lower down than Stirling. But for the greater part of the year the whole of these feeders are practically clear of sediment, and the load of detritus they transport during the short periods of flood is quite inadequate to account for the enormous quantity of suspended mud in the salt water of the Estuary. At most times of the year the Forth at Stirling is in fact a perfectly clear river, brown in colour, but fairly transparent and pure. No doubt the clay of the carse land and the sleeches has been originally all washed down as river alluvium, but that was the work of ages-of the many thousands of years that have elapsed since the Ice Age. If all the carse lands had been silted up as fast as the sheltered places and harbours in the Estuary, the whole operation could have been completed in a single lifetime.

Rate of Siltation.-The writer has had many opportunities of noticing the rate of siltation in the Forth. In 1889 a piece of foreshore, some thirty acres in extent, was surrounded by a low embankment of stones and rubbish at Bridgeness, just east of Bo'ness. The bank was made near low-water line when the tide was out, and at high 
tide was covered by about 6 feet of water. The lower part of the foreshore, which at that place is 300 yards broad, was thus converted into a lagoon in which the water lay quiet, and could deposit its sediment at every tide. When the enclosed mud had risen level with the top of the great bank, a second was constructed above it, and when it was likewise buried, a third bank was finally laid down to exclude the tide from the intake, as shown in the accompanying diagrammatic section. The vertical scale of this is greatly exaggerated.

A regular record was kept of the rate of siltation over the whole area, and the average depth to which the mud accumulated was found to be about 1 inch per month, or 1 foot per annum, but at the beginning of operations the rate at some places was 3 feet in the first year. During storms and spring tides there was more precipitation of mud than during calm weather, or at neap tides when the depth of water on the bank was smaller. At the end of ten years the mud gauge showed that the rate of deposit had diminished, but during the whole period 10 feet of silt had been deposited inside the bank. By that time the foreshore had become so shallow that it was barely covered at high

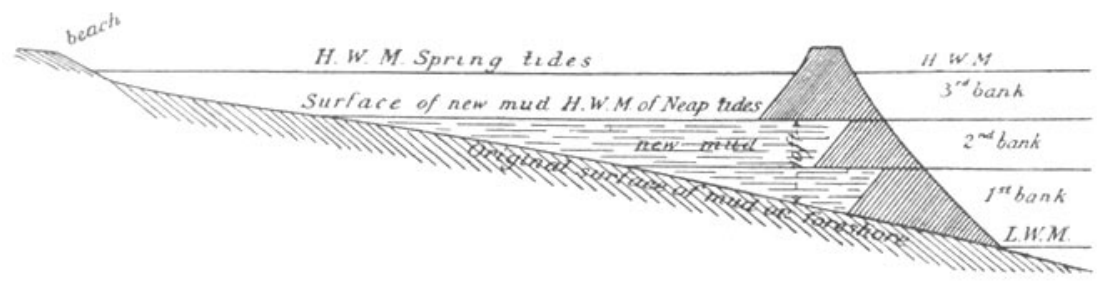

Sketch showing aceumulation of silt within successive embankments at Bridgeness.

water during neap tides, and as there remained room for so little water in the enclosure the rate of siltation was of course greatly reduced.

At other places in the vicinity the mud has been observed to silt up much faster. Two or three feet or more per annum have been noted, and since the war began I have been told that from the time the harbours were closed in November 1914, till the end of 1917, the mud had accumulated to a depth of 10 or 12 feet in some of them where no dredging had been going on during that period.

Origin of the Forth Mud.-Little reflection is required to convince the observer that all this sediment is not directly derived from the River Forth at all, and the question arises, Where then does it come from? Of late it seems to have become more plentiful than ever, and especially since the great dredging operations at Rosyth have been in progress. My answer is that most of the mud is derived from the adjacent sleeches, which in stormy weather are scoured by the rain when the tide is out or flogged by the waves when it comes in, the agitated suspended material being redeposited wherever the water is tranquil. There is also good reason to suppose that the mud is washed upp the Firth as well as down, and is deposited in the upper reaches at high tide when the current is slack for a short time.

The Forth is open to the east, and sheltered from the west winds, 
and on the south shore the spits and banks of sand and gravel on the beach tend to travel westwards up the Estuary, according to the prevailing play of the waves. Since Port Edgar pier was extended seawards in 1877-78, a great bank of sand has been drifted up on the west side, but the east side of the harbour outside the brealswater has remained clear. Inside the harbour the mud has silted up to a depth of several feet, requiring much dredging before it could be used again. The sandbank on the lee side shows the direction of the prevailing currents and wave action to be from the east, and if sand can be swept westwards so can mud, but to a much greater degree.

These hydrographical and physical considerations may seem to have only a remote connection with the industrial possibilities of the Forth. But in reality they have, as I shall later on attempt to show, an exceedingly important bearing on a large part of the question.

The after-war development of each of the three sections of the Estuary may now be discussed separately.

The eastern section being inside Rosyth Harbour is mainly outwith the scope of this paper except in one important particular that may now be mentioned.

Blackness.-Port Edgar is now in the hands of the Admiralty, and is being rapidly extended for naval purposes. South Queensferry, to which Port Edgar is now being joined, is an old town, with a narrow and crooked main street, badly planned to begin with, on which local greatness has recently been thrust. It is becoming largely used by naval men and their families on shore, but what seems desirable is a better residential town or village, laid out de novo near the Naval Base, with more amenity for a pleasant existence, and well away from smoke and the noise of industry.

Now it must be noticed that the number of well situated, healthy, and convenient sites along the shores of the Firth of Forth for garden cities and villages above the Bridge is strictly limited. On the north side, west of Crombie, the shore of Torry Bay is very muddy, and the whole of the beach from Torryburn and Culross westwards has been quite destroyed in recent years, so far as amenity and access to the sea is concerned, by the N.B. Railway line from Kincardine to Dunfermline.

As has been noted, the whole Estuary above Carriden, on the south shore, is fringed with muddy foreshores, where there is practically no riparian amenity to lose. But below Carriden, for a distance of $5 \frac{1}{2}$ miles to Port Edgar, the water is somewhat clearer, and the foreshores and beaches are relatively clean and sandy, so that boating and bathing are practicable, and the beaches are such that children can play upon them with some pleasure, a thing that is naturally impossible farther up the river.

My suggestion therefore is that now, before any more works or railway lines are planned, this piece of the coast, including Hopetoun policies, should not be industrialised but permanently reserved for amenity and for residential purposes only, and that the village of Blackness, situated near the centre of it, should be turned into a residential garden city or village, for which it is in several respects very well adapted. Blackness 
Castle-kept up by the Government, it is popularly, but it seems quite erroneously, supposed, according to the Treaty of Union in 1707-was used for nearly fifty years as a magazine for explosives, but has lately been abandoned, and it is now quite empty. It was formerly a place of great strength, and is directly opposite to Charlestown, a short distance west of Rosyth. The castle has a short open pier where explosives used to be shipped, but it does not extend to low-water mark. The pier might well be extended for use at all times of the tide, and a ferry established to Charlestown or Rosyth by which naval men could easily land either from their ships or from the north shore, and make their homes here in some degree of peace and rural quietness within sight of but well away from the smoke and bustle of the mushroom city of Rosyth.

Blackness is only two miles from Philpstoun Station on the N.B. Railway to Edinburgh, and to complete the scheme I would now suggest that a new road, less than three miles in length, be constructed up to the station on an easy gradient, on which rails should be laid for oil or petroldriven cars to take passengers quickly to the main line. By this means an alternate passengor route from Rosyth to Edinburgh would be provided more convenient in some ways than the Forth Bridge route. A new road two miles long should also be made along the shore from Blackness to Carriden instead of the present footpath, so as to provide easy communication with the railway at Bo'ness three and a half miles off. Indeed the proprietor of Carriden estate, which covers two-thirds of the distance, has lately begun the construction of the western end of this proposed highway.

Another shore road could be advantageousiy made eastwards to Port Edgar. Before the Union in 1707 there was a shore road all the way from Bo'ness to Leith, I believe, known as the King's Highway, but it was closed for vehicular traffic long ago, and has since been all washed away by the waves. Recent developments point to the advantage of restoring the old King's Highway for the use of the lieges. It would make Blackness accessible from three directions.

The district will be well supplied with water when the new reservoir the County Council are constructing above Linlithgow is finished. Good quarries of building stone exist in the district, and there are excellent building sites in a healthy and pleasant locality in full view of Rosyth, so that the place has many natural advantages to recommend it.

Blackness Castle is a grim and unpicturesque fortress, with no features of architectural interest, but it might be greatly improved in appearance if it was planted with ivy or ampelopsis. It is not likely to be of much further use to the army or navy, but the powder magazine inside the great walls might be removed and the old courtyard restored as I remember it fifty years ago before the magazine was built. The building could be altered so as to be used for a veteran sailors' home or a club-house for service dwellers in Blackness, and let by the Government at a small rent to any society or public body willing to carry out such a proposal and keep it in preservation. The barracks and barrack-yard that were placed in the usual ugly military style outside the gate half a 
century ago are modern structures, and could be beautified and let for dwellings or used as part of the proposed establishment. The castle has no important historic associations except as a prison for Reformers and Covenanters in the persecuting days of James VI. and the later Stuarts, and might well be permitted to add a final and happier chapter to its dim and dismal annals.

The second section of the Estuary may now be discussed.

Bo'ness.- The industrial fringe on the south shore begins at Carriden and extends to Bridgeness, Bo'ness and Kinneil, covering a distance of more than two miles of the coast. Bridgeness has a tidal harbour large enough for vessels of 1000 tons, and is mainly used for shipping coal from Bridgeness Colliery, but it is capable of enlargement, and wharfage facilities can easily be extended. The foreshore, about 300 yards broad, has lately been reclaimed in the vicinity out to low-water mark. The reclamation of more ground is still in progress, and there is a considerable and increasing area of flat land available for public works or shipbuilding close to the harbour. A ship-breaking company has been at work here for several years, and the reclaimed land is largely used for timber yards by importers of pitwood at Bo'ness.

Bo'ness Harbour and Dock, a mile west of Bridgeness, connected to the main line by a single line branch railway, belongs to the N.B. Railway Company, and in normal times is largely used for coal shipping and discharging timber from Scandinavia. The dock can take in ships up to 3000 tons capacity. The town has for industries collieries, potteries, woodyards, sawmills, chemical works, foundry and engineering works, and other branches of trade. It is well provided with water, gas, and electricity, and the part of the burgh on the higher ground overlooking the sea is laid out in handsome new streets for a growing population. There are excellent schools, including a secondary academy, and a golf course and other amenities of a modern kind. The population of the parish, which includes the burgh, is about 14,000 .

To the west of Bo'ness, the foreshore, as has been said, opens out till it is more than a mile broad and is well adapted for extensive reclamation. Schemes have been proposed at different times during last century to embank large areas between Bo'ness and Grangemouth, but the only land that has been reclaimed here is a fringe along the shore somewhat over fifty acres in extent. This was mainly filled up by the slag from the Kinneil blast furnaces, which began work in 1853 and ceased operations more than thirty years ago, but a certain amount of colliery refuse is still being deposited on a part of the foreshore of Kinneil. Large bings of colliery rubbish surround the numerous old pits on the adjacent high ground, and these might be cheaply brought down to the sea for reclamation purposes, leaving the land clear for agriculture.

Along this part of the shore between Bo'ness and Grangemouth there is no amenity to lose, and if the foreshore were reclaimed there would be provided extensive sites for various kinds of works adjacent to low-water mark with tidal wharves alongside of them, while the low-lying part next the shore, not required for industrial operations, would make good agricultural land well adapted for wheat and beans and grazing. 
Grangemouth.-The extensive harbour and docks belong to the Caledonian Railway Company, and extend across the foreshore to lowwater line. These works, which form the latest reclamation of any size in the Estuary, cover 260 acres of the foreshore at the mouth of the Carron Water. The distance from the outer end of the Grangemouth Dock to Bo'ness Harbour is three miles as the crow flies, and a great part of the intervening foreshore in the bay is not covered by more than six feet of water at high tides. Besides the harbour, Grangemouth has for industries the timber trade and shipbuilding, and there is ample room as well as facilities for a great development of business. The docks are the largest in this part of the Firth, and can take in ships up to 5000 tons capacity, and, if the foreshores were reclaimed alongside the harbour, excellent sites would be available for industries connected with marine transport, or for shipbuilding on a large scale. Grangemouth, which is on the carse, and is well supplied with water, is near the Carron ironworks, and the large foundries of the Falkirk district are within three miles of the harbour.

Alloa is situated at the head of the Estuary proper, and has a small dock, owned by the North British Railway Company, used principally for shipping coal from the Alloa coalfield. There are two shipbuilding yards where vessels up to 300 feet in length are being built. The industries include engineering and agricultural machinery works, textiles, glass-blowing, and brewing. South Alloa, connected with the Caledonian Railway, is largely laid out for timber yards for imported pitwood. There is space for much development of shipping, but what is most wanted, both here and at Bo'ness and Grangemouth, is improvement of the channel for navigation.

River Conservancy.-The harbours of Bo'ness and Grangemouth, as well as Alloa are, as we have seen, greatly injured by the mud that steadily chokes up their entrances, and in normal times it costs the two former some $£ 4000$ to $£ 6000$ a year each to keep them clear of silt.

For many years the Forth has been greatly in need of a Conservancy Board, similar to the Clyde Trust, to dredge the channel, reclaim the foreshores, and generally to promote the trade of the Estuary and the shipping interest. The large harbours are all owned by one or other of the two railway companies, who have not shown very broad views as to the development of trade beyond their immediate and somewhat limited circle of vision. Each company has been too apt to regard the other merely as a competitor, and combined action in the public interest has not often been considered. Now that there is some prospect of a more national policy being adopted, the whole question of the development of the trade of the Forth may be simplified. The idea of a Forth Conservancy is not a new one, but the want of any cohesion among the various interested parties has hitherto prevented any practical steps being taken in the matter.

The total registered tonnage before the war of vessels entering and leaving the Forth ports above Queensferry was over four million tons a year, and after the war it may be much greater. The conservation and development of the Forth shipping industry is thus of paramount 
importance. It is now more important than ever, and the proposal has the entire approval of the municipalities of Bo'ness, Grangemouth, and Alloa.

What is required in the first instance is a conference of representatives of the Admiralty, the riparian counties and municipalities, the railway companies, and the shipping, landed, and trading interests, to formulate some practicable scheme, and to obtain an Act of Parliament giving the proposed Board the necessary powers, including the power to levy conservancy dues on all shipping affected by its operations. If all interested parties were to agree enthusiastically to support such a Bill, so that it might be passed without opposition, and without unnecessary expense and delay, the first difficulty would be removed, and preliminary arrangements might begin, and the sooner the better, as there is much to consider before any practical operations can be commenced.

(To be continued.)

\section{PROCEEDINGS OF THE ROYAL SCOTTISH GEOGRAPHICAL SOCIETY.}

AT a meeting of Council held on Monday, March 25th, Mr. John Mathieson, F.R.S.G.S., was appointed interim Honorary Map Curator in succession to Colonel Sconce, resigned. At the same meeting Mr. W. G. Burn-Murdoch, J.P.; Mr. W. L. Calderwood, Director of Scottish Salmon Fisheries; Mr. Harry R. G. Inglis ; Principal A. P. Laurie, M.A., D.Sc., F.R.S.E., and Mr. A. Watt, M.A., F.R.S.E., Secretary to the Scottish Meteorological Society, were unanimously elected to fill vacancies in the Council.

The Diploma of Fellowship was conferred upon Mr. W. H. Menmuir, L.D.S., who has travelled extensively in Europe, and made a special study of the geography of Russia.

The following were elected members of the Society at a Council meeting held in January :-

Ordinary Members.

Miss L. Lumsden, LL.D.

Miss J. C. Ross.

Arthur O. Cooke.

Thomas Dunlop.

Harry R. G. Inglis.

Major J. Hay.
Associate Members.

Miss J. C. Connor, M.A.

Miss I. Abel.

Miss I. Beattie.

Miss J. J. Gillespie.

Mr. M. S. Odabashian.

James C. Barrowman, M. A.

The following were elected at the March meeting :-

\section{Ordinary Members.}

Major J. G. Allan, D.S.O.

Roland E. Muirhead.

Rev. Hubert L. Simpson.

Walter H. Young.

William H. Menmuir, L.D.S.
Associate Members.

Miss E. M. Eaves.

Ernest E. Gomersall, B.Sc. 